\title{
PEMBUATAN VIDEO KAMPANYE INFORMASI KEPADA MASYARAKAT "RESAH KARENA PHK? AYO BISNIS AJA!"
}

\author{
Fajarina, Euis Nurul Bahriyah \\ Fakultas Ilmu Komunikasi, Universitas Esa Unggul, Jakarta \\ Jalan Arjuna Utara No. 9 Tol Tomang, Kebon Jeruk, Jakarta Barat - 11510 \\ fajarina@esaunggul.ac.id
}

\begin{abstract}
Campaigns or educational campaigns in the form of short educational videos through social media such as Youtube are becoming increasingly popular among many people. Worried Because of Layoffs? Come on Business! is the title of the video campaign which is carried as 'Information to People Affected by Layoffs' due to the current Covid 19 pandemic conditions experienced by people around the world including Indonesia, making the Government decide to lock down all activities outside the home including studying at educational institutions and working in an office. This makes many employees at home. The impact that occurs because many employees are at home indirectly causes the company's activities to stop operating, especially in manufacturing, industry and others. This has forced many companies to have to lay off some of their employees because they are unable to pay employees salaries or wages that are not proportional to company income during the pandemic. In fact, many companies have been forced to close their businesses and this has resulted in layoffs (Termination of Employment). This educational video campaign is a video designed for the benefit of the community. The aim is none other than to encourage employees affected by layoffs to start thinking about business alternatives to doing business. This short video provides an example of the types of business laid-off employees can do, complete with first-hand experience of several laid-off employees who are quite successful in trying on their own as well as a few tips and tricks from a financial consultant that are quite useful for novice businessmen.
\end{abstract}

Keywords : video campaign, phk, business, pandemi, covid 19

\begin{abstract}
Abstrak
Campaign atau kampanye mendidik dalam bentuk video edukasi berdurasi singkat melalui media sosial seperti Youtube menjadi marak dilakukan oleh banyak orang. Resah Karena PHK? Ayo Bisnis Aja! merupakan judul dari video campaign yang diusung sebagai 'Informasi Kepada Masyarakat Yang Terdampak PHK' dikarenakan kondisi pandemi covid 19 saat ini yang dialami masyarakat seluruh dunia termasuk Indonesia, membuat Pemerintah memutuskan untuk mengLockdown seluruh kegiatan di luar rumah termasuk menuntut ilmu di lembaga pendidikan dan bekerja di perkantoran. Hal ini menjadikan banyak karyawan yang di"rumah"kan. Dampak yang terjadi karena banyak karyawan di"rumah"kan secara tidak langsung membuat kegiatan perusahaan terhenti beroperasi khususnya bagian manufaktur, industri dan lain-lain. Hal ini membuat banyak perusahaan terpaksa harus memberhentikan sebagian karyawannya karena tidak sanggup membayar gaji atau upah karyawan yang tidak sebanding dengan pemasukan perusahaan selama pandemi. Bahkan banyak perusahaan terpaksa menutup usahanya dan ini pun membuat seluruh karyawannya mengalami PHK (Pemutusan Hubungan Kerja). Kampanye video edukasi ini merupakan video yang dirancang untuk kepentingan masyarakat. Tujuannya tidak lain untuk menyemangati para karyawan yang terkena PHK untuk mulai beralih memikirkan alternatif usaha dengan berbisnis. Video singkat ini menginformasikan contoh jenis usaha yang bisa dilakukan para karyawan yang terkena PHK lengkap dengan pengalaman langsung beberapa orang karyawan yang terkena PHK yang cukup berhasil berusaha sendiri serta sedikit tips dan trik dari seorang konsultan keuangan yang cukup berguna bagi pebisnis pemula.
\end{abstract}

Kata kunci : video kampanye, phk, bisnis, pandemi, covid 19

\section{Pendahuluan}

Campaign atau kampanye mendidik dalam bentuk video edukasi berdurasi singkat melalui media sosial menjadi sangat marak dilakukan banyak orang. Apalagi di masa pandemi Covid-19 yang beberapa bulan ini dirasakan oleh seluruh belahan dunia. Kita jadi memiliki banyak waktu di rumah, menikmati hiburan melalui smartphone, tablet atau smart TV merupakan kebiasaan yang mengasyikkan, disamping itu quality time bersama keluarga juga semakin erat. Begitu banyak video edukasi mengenai pandemi Covid-19, dari bagaiman cara hidup bersih, hidup sehat, siasat WFH (Work 
From Home), menghadapi tantangan PHK, mengatur keuangan dan lain-lain.

Kondisi riil masyarakat Indonesia masih menunjukkan kuatnya budaya lisan dan rendahnya budaya membaca, dimana secara umum masyarakat kurang akrab dengan kegiatan membaca. Atas kondisi ini menjadikan video edukasi sebagai bentuk sosialisasi terhadap masyarakat patut diperhitungkan. Tidak hanya berupa audio saja namun penambahan visual yang menarik memungkinkan masyarakat lebih mudah mencerna dibanding hanya dengan visual (membaca).

Resah Karena PHK? Ayo Bisnis Aja! merupakan judul dari video campaign yang diusung sebagai 'Informasi Kepada Masyarakat Yang Terdampak PHK'. Alasan memilih judul tersebut karena kondisi ini yang banyak dialami masyarakat kita, sejak Pemerintah memutuskan untuk Lockdown, atau di Indonesia disebut PSBB (Pembatasan Sosial Berskala Besar) menjadikan banyak karyawan yang dirumahkan. Dampak yang terjadi karena banyak karyawan dirumahkan secara tidak langsung kegiatan perusahaan berhenti khususnya bagian manufaktur, industri dan lain-lain. Meski pada akhirnya Pemerintah memutuskan membuka kembali struktur ekonomi asal semua sesuai protokol kesehatan, tidak menjadikan berita baik bagi semua masyarakat. Bidang usaha yang terlanjur tidak bertahan saat PSBB sudah pasti akan menutup usahanya. Semua seperti rantai yang saling berkaitan, karena konsumen tidak ada permintaan maka produksi berhenti, karena produksi yang terhenti tersebut, maka karyawan mau tidak mau harus di-PHK.

Kata-kata Pemutusan Hubungan Kerja membuat masyarakat takut bagaimana menghadapi kelangsungan hidup selanjutnya, apa yang harus dilakukan, apakah berhasil, bisakah hidup tenang, dan masih banyak pikiran berkecamuk. Video ini bertujuan menyemangati para karyawan yang terkena PHK untuk bangkit dan mulai berwiraswasta agar perekonomiannya kembali stabil.

\section{Tinjauan Pustaka \\ Pemutusan Hubungan Kerja}

Menurut Undang-Undang No. 13 Tahun 2003 mengartikan bahwa Pemberhentian atau Pemutusan Hubungan Kerja adalah pengakhiran hubungan kerja karena suatu hal tertentu yang mengakibatkan berakhirnya hak dan kewajiban antar pekerja dan pengusaha. Manulang (1998) mengemukakan pemutusan hubungan kerja terdapat beberapa istilah berdasarkan penyebab pemutusan hubungan kerja tersebut, diantaranya :

a. Termination, yaitu putusnya hubungan kerja karena selesainya atau berakhirnya kontrak kerja yang telah disepakati. Berakhirnya kontrak, bilamana tidak terdapat kesepakatan antara karyawan dengan manajemen, maka karyawan harus meninggalkan pekerjaanya.

b. Dismissal, yaitu putusnya hubungan kerja karena karyawan melakukan tindakan pelanggaran disipilin yang telah ditetapkan.

c. Redundancy, yaitu pemutusan hubungan kerja karena perusahaan melakukan pengembangan dengan menggunakan mesin-mesin berteknologi baru, seperti penggunaan robotrobot industry dalam proses produksi, penggunaan alat-alat berat yang cukup dioperasikan oleh satu atau dua orang untuk menggantikan sejumlah tenaga kerja yang dalam hal ini berdampat pada pengurangan tenaga kerja.

d. Retrenchment, yaitu pemutusan hubungan kerja yang dikaitkan dengan masalah-masalah ekonomi, seperti resesi ekonomi, masalah pemasaran, sehingga perusahaan tidak mampu untuk memberikan upah kepada karyawannya.

Dalam kasus pandemic Covid19 seperti sekarang ini, tentunya perusahaan mau tidak mau merumahkan sebagian karyawannya agar perusahaan tersebut dapat bertahan. Penerapan PSBB atau Pembatasan Sosial Berskala Besar dalam memutus mata rantai penyebaran virus Covid19 oleh pemerintah memiliki dampak yang cukup besar bagi perusahaan. Banyaknya karyawan yang dirumahkan karena hal ini. Berdasarkan istilah PHK yang sudah disebutkan sebelumnya, retrenchment merupakan sebutan yang tepat dalam kasus ini. Dikutip dari portal berita online Kompas.com berdasarkan data yang teregister di Kemenaker sampai bulan Juli 2020, terdapat 3 juta tenaga ker di Indonesia yang dirumahkan akibat pandemic. Namun data tersebut tidak dapat dijadikan patokan karena masih banyak perusahaan yang belum melaporkan data PHK tersebut. Untuk wilayah Bekasi sendiri terdapat 1.651 buruh yang mengalami pemutusan hubungan kerja akibat dari pandemic ini. Dilansir dari portal berita Okenews, sejumlah perusahaan di Kabupaten Bekasi dipastikan belum dapat membuka kesempatan kerja setelah anjloknya perekonomian akibat pandemi Covid-19. Meski industri telah diperbolehkan beroperasi, mereka tetap kesulitan memulai produksi akibat dari hal tersebut. Namun meskipun begitu, perusahaan tempat para buruh bekerja masih tetap memberikan uang pesangon sebagai kompensansi dari dirumahkannya para pekerja tersebut. Diberikannya uang pesangon kepada pekerja yang terpaksa harus dirumahkan, tentunya pekerja atau masyarakat tersebut harus pintar dalam mengelola pesangon yang diberikan. 
Menurut Ibu Mieke Rini Sutikno, seorang Financial Planner Mitra Rencana Edukasi, ada beberapa hal yang harus diperhatikan dalam mengelola pesangon. Diantaranya:

a. Alokasikanlah uang pesangon untuk modal usaha yakni sebesar 25\% sampai 30\%, atau tidak melebihi 50\%. Karena tentunya dalam membangun suatu usaha pasti ada pasang surutnya. Selain itu, kita juga harus menggunakan uang pesangon untuk kebutuhan hidup sehari-hari.

b. Pilih usaha yang tepat dan sesuai dengan kemampuan kita. Apabila masyarakat belum mempunyai pengalaman dalam hal ini membuka usaha, berjualan adalah pilihan yang tepat. Berjualan bisa dengan membuka sebuah toko di rumah, atau berjualan online dari rumah. Dengan pengelolaan uang pesangon tersebut, diharapkan masyarakat yang terdampak pandemic dengan dirumahkan bisa membuka usaha di rumah sehingga bisa tetap berpenghasilan.

\section{Berwirausaha}

Berwirausaha merupakan hal yang sedang ramai di era seperti sekarang ini. Secara Etimologi wirausaha berasal dari kata "wira" dan "usaha". "Wira" memiliki arti yakni pejuang, pahlawan, manusia unggul, teladan, berbudi luhur, gagah berani dan berwatak agung. Sedangkan "usaha" berarti perbuatan untuk mencapai sebuah tujuan. Menurut Geoffrey G. Meredit (1995) wirausaha adalah orang yang memiliki kemampuan melihat dan menilai kesempatan-kesempatan bisnis mengumpulkan sumber-sumber daya yang dibutuhkan guna mengambil keuntungan daripadanya serta mengambil tindakan yang tepat, guna memastikan kesuksesan. Sedangkan menurut Prawirokusumo adalah mereka yang melakukan upaya-upaya kreatif dan inovatif dengan jalan mengembangkan ide dan meramu sumber daya untuk menemukan peluang dan perbaikan hidup. Jadi wirausaha adalah sebuah upaya yang dilakukan oleh manusia dalam mengembangan hidupnya dengan kreatif dan inovatif untuk mencapai suatu tujuan, yaitu kesuksesan.

Dalam prosesnya, wirausahawan mengombinasikan faktor-faktor produksi seperti sumber daya alam, tenaga kerja, material dan peralatan lainnya, serta melakukan sebuah proses yang disebut creative destruction (pengerusakan yang kreatif) untuk menghasilkan nilai tambah (added value) guna menghasilkan nilai yang lebih tinggi, sehingga inti dari keterampilan wirausaha adalah kreativitas (the core of entrepreneurial skill is creativity).
Maka dari itulah, wirausaha adalah pelaku utama dalam pembangunan ekonomi yang fungsinya untuk melakukan inovasi atau kombinasi-kombinasi yang baru untuk sebuah inovasi sehingga melakukan perbaikan produkasi lainna. Juga memiliki dorongan kekuatan dari dalam diri untuk memperoleh suatu tujuan, serta suka bereksperimen untuk menampilkan kebebasan dirinya di luar kekuasaan dari orang lain. Seseorang dikatakan wirausaha tentu memenuhi definisi wirausaha itu sendiri, seperti :

a. Memiliki keberanian mempunyai daya kreasi

b. Berani mengambil risiko

c. Memiliki semangat dan kemauan keras

d. Memiliki analisis yang tepat

e. Tidak konsumtif

f. Memiliki jiwa pemimpin

g. Berorientasi pada masa depan

Di tengah pandemic seperti sekarang ini, tentunya masyarakat yang terkena PHK harus mencari upaya dalam mempertahankan hidupnya agar berpenghasilan yakni dengan berwirausaha. Banyak sekali contoh-contoh alternatif usaha dari yang paling mudah dengan modal yang kecil, sampai yang paling rumit dengan modal yang paling besar. Dalam kasus seperti sekarang ini, tentunya tidak semua masyarakat sudah berpengalaman dalam berwirausaha sebelumnya. Sehingga peluang untuk gagal pun sangat besar. Oleh karena itu, hadirnya video edukasi ini bertujuan untuk memberikan beberapa contoh alternatif usaha agar masyarakat bisa mendapatkan sedikit pencerahan sebelum membuka suatu usaha itu sendiri.

\section{Video Edukasi}

Video edukasi dengan jenis campaign video merupakan salah satu jenis video yang populer di video situs-situs hosting atau video sharing, baik kampanye politik maupun sosial (Media, Laksamana 2019:15). Jenis video ini menampilkan rekaman dari kegiatan kampanye yang dilakukan oleh partai politik, lembaga swadaya masyarakat, atau instansi pemerintah yang berisi ajakan untuk berpartisipasi dalam mensukseskan kegiatan yang dicanangkan. Dalam video kampanye sosial dapat diciptakan dengan cara membuat rekaman yang berisi ajakan untuk peduli terhadap kelestarian lingkungan dan sebagainya. Hal yang harus diperhatikan dalam pembuatan video edukasi adalah pemilihan kata-kata yang tepat serta bersifat persuasive. Karena video jenis ini berisi ajakan untuk berpartisipasi dalam mensukseskan kegiatan tertentu. 


\section{Motion Graphics}

Untuk membuat video edukasi yang menarik tentunya harus diperhatikan komponenkomponen yang ada didalamnya, termasuk mau seperti apa isi video tersebut. Apakah secara keseluruhan berisikan rekaman video, ataupun animasi motion graphics. Motion Graphics adalah istilah yang digunakan untuk menggambarkan berbagai solusi yang digunakan oleh para profesional desain grafis untuk menciptakan desain komunikasi yang dinamis dan efektif untuk film, televisi, dan internet. Motion Graphics menggabungkan komponenkomponen seperti desain, pembuatan film, tulisan, animasi, arsitektur informasi dan desain suara. (Curran, 2000:3). Sedangkan menurut Nuga Choiril, motion graphic merupakan salah satu cabang ilmu desain grafis, dimana dalam motion graphic terdapat elemen-elemen desain seperti bentuk, raut, ukuran, arah, tekstur di dalamnya, dengan secara sengaja digerakkan atau diberi pergerakan. Perbedaan motion graphic dengan desain grafis adalah pada media aplikasinya, apabila pada desain grafis elemen-elemennya statis (diam) dan terdapat pada media cetak, sementara elemen pada motion graphic memiliki gerakan sehingga terlihat dinamis dan ditampilkan melalui media audio visual. (Umam, 2016).

Terdapat beberapa pembagian visual yang dapat menghasilkan motion graphics secara secara efektif namun tetap menarik, yaitu:

a. Spatial merupakan pertimbangan ruangan, terdiri dari arah, ukuran, arah acuan, arah gerakan, perubahan ketika gerakan dipengaruhi gerakan lain, hubungan pergerakan terhadap batas - batas frame.

b. Temporal, merupakan sebuah pertimbangan yang berhubungan dengan time (waktu) dan velocity (kecepatan), serta memiliki peranan dalam sebuah pergerakan. Di dalam video ataupun motion graphic, waktu digambarkan secara frame per second.

c. Live action, faktor - faktor yang perlu diperhatikan ketika bekerja dengan konten live action termasuk bentuk atau konteks, property film, dan sifat sinematik, seperti tone, contrast lighting, depth of field, focus, camera angle, shot size, dan mobile framing.

d. Typographic Type, merupakan salah satu prinsip untuk membangun sebuah persen dalam desain grafis. Dalam penggunaan type terdapat beberapa hal yang bisa dimanfaatkan sesuai dengan kebutuhan, misalnya tipe huruf, ukuran weight, capital atau lowercase.
Motion Graphics membawa sejumlah manfaat. Beberapa informasi terlalu rumit untuk disajikan dalam gambar diam, yang berarti infografis harus dikecilkan atau kurang dari perincian yang komprehensif. Motion graphics dapat menampilkan gambar yang berbeda dengan menggunakan video dan audio untuk memberikan gambar yang lebih besar. Komponen yang terlibat pun tidak hanya mata, tetapi juga telinga. Sehingga informasi dapat lebih mudah diingat daripada hanya berupa bagan atau teks sederhana.

Perangkat lunak yang diperlukan dalam membuat motion graphics yaitu :

a. Perangkat lunak untuk membuat dan mengolah ilustrasi vector dan tipografi, yakni Adobe Illustrator

b. Perangkat lunak untuk mengolah foto yaitu Adobe Photoshop

c. Perangkat lunak untuk membuat, mengolah, mengomposisi dan menciptakan Motion Graphics, yaitu Adobe After Effect dan Adobe

Premiere

d. Dan yang terakhir perangkat lunak untuk mengedit suara yaitu Adobe Audition

Keempat perangkat lunak tersebut digunakan dalam pembuatan Video Campaign yang berjudul "Resah Karena PHK? Ayo Bisnis Aja!". Dalam proses pembuatannya tentunya harus dipilih konsep dan tema yang tepat dalam menyampaikan informasi dalam bentuk video motion graphics. Selain itu, pembagian tim kerja, pemilihan talent dan narasi cerita juga perlu disiapkan. Untuk itu prosedur ideal harus dipersiapkan dengan benar guna mencapai akhir yang sesuai keinginan.

c. Pilih usaha yang tepat dan sesuai dengan kemampuan kita. Apabila masyarakat belum mempunyai pengalaman dalam hal ini membuka usaha, berjualan adalah pilihan yang tepat. Berjualan bisa dengan membuka sebuah toko di rumah, atau berjualan online dari rumah.

Dengan pengelolaan uang pesangon tersebut, diharapkan masyarakat yang terdampak pandemic dengan dirumahkan bisa membuka usaha di rumah sehingga bisa tetap berpenghasilan.

\section{METODE PELAKSANAAN}

\section{Konsep Kreatif}

Kategori Program :

Edukasi 
Deskripsi Program :

Merupakan sebuah video kampanye edukasi yang ditujukan kepada masyarakat luas yang terdampak PHK akibat dari pandemic Covid19. Tentunya masyarakat yang terdampak PHK akan mencari cara agar dirinya tetap berpenghasilan.

\section{Format Program :}

Video Kampanye Edukasi

Judul Program :

Resah Karena PHK? Ayo Bisnis Aja!

Durasi Program :

Hasil akhir video kampanye edukasi ini berdurasi 3 menit, termasuk didalamnya Opening Video, Opening Title, serta Credit Title yang akan berdurasi 1 menit, dan 2 menit berikutnya yakni isi alur cerita dari video kampanye edukasi ini.

Target Audiens :

Masyarakat yang terdampak PHK akibat pandemic Covid19

a. Usia : Dewasa (18-35 tahun), Orang Tua (>36 tahun)

b. Jenis Kelamin : Pria dan Wanita

c. Status Ekonomi Sosial :

Menurut Lloyd Warner, kelas sosial dapat dibagi menjadi 6 bagian yaitu :

1. Kelas atas - atas $(\mathrm{A}+)$

2. Kelas atas bagian bawah (A)

3. Kelas menengah atas $(\mathrm{B}+)$

4. Kelas menengah bawah (B)

5. Kelas bawah bagian atas $(\mathrm{C}+)$

6. Kelas bawah bagian bawah (C)

Segmentasi status sosial yang digunakan pada program ini pada bagian B sampai dengan A. karena konten yang ada didalam program ini memberikan edukasi dan informasi terutama untuk masyarakat yang terdampak PHK agar dapat survive untuk mencari alternatif usaha lain dan gaya Bahasa yang digunakan untuk dapat diterima oleh audiens agar pesan yang diberikan tersampaikan dengan baik.

Rencana Tayang :

Video ini akan ditayangkan di Youtube dan Instagram TV.

Jadwal Produksi

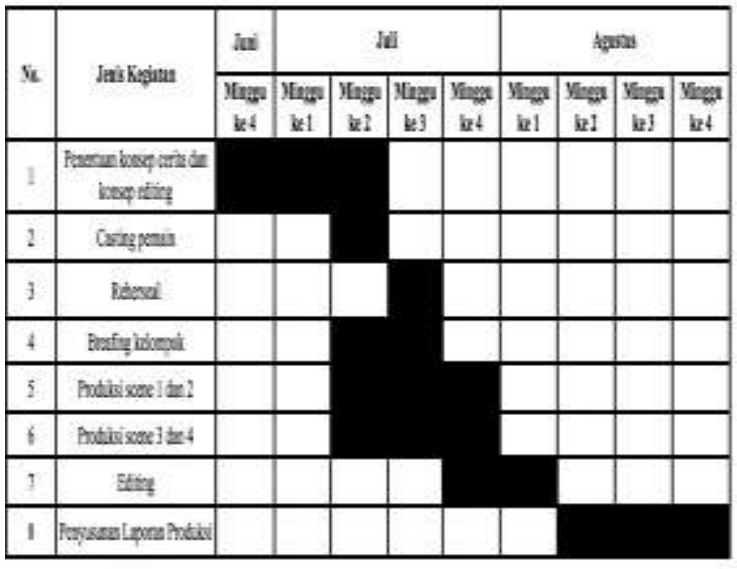

\section{Hasil dan Pembahasan}

Keterampilan produksi merupakan hal yang mendasar pada proses pembuatan program di dunia pertelevisian, tanpa keahlian ini program yang baik serta unik tidak dapat dibuat. Tetapi keterampilan saja tidak cukup, kreatifitas serta kemampuan berpikir yang dimiliki juga sangat berpengaruh agar terciptanya suatu program yang sukses.

Kegiatan video kampanye ini terdiri dari serangkaian tahapan yang meliputi perencanaan (pra produksi), pelaksanaan (produksi), dan editing serta launching (pasca produksi) dan cukup banyak melibatkan personil yang mengambil peran dan tugasnya masing-masing.

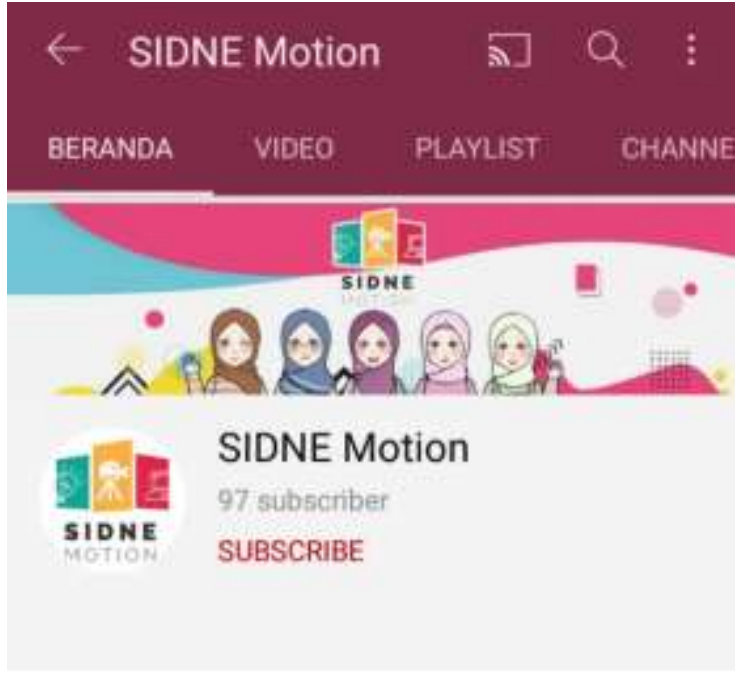

Upload

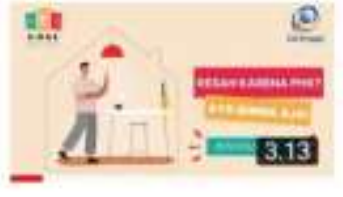

RESAH KARENA PHK? AYO BISNIS AJA! $673 \times$ ditonton - 5 bulan yang

Adapun peran dalam pembuatan video kampanye ini terdiri dari produser, sutradara, 
research data dan script writer, voice over dan audio editor, serta editor dan motion graphic.

Video kampanye ini mengambil tempat di Kota Bekasi dan telah di-launching di media sosial YouTube melalui channel SIDNE Motion dengan link RESAH KARENA PHK? AYO BISNIS AJA! YouTube pada bulan Agustus 2020 dimana hingga saat ini jumlah subscribers-nya sebanyak 97 dan telah ditonton sebanyak 668 views dan mendapat like sebanyak 213 dan cukup mendapat komentar positif.

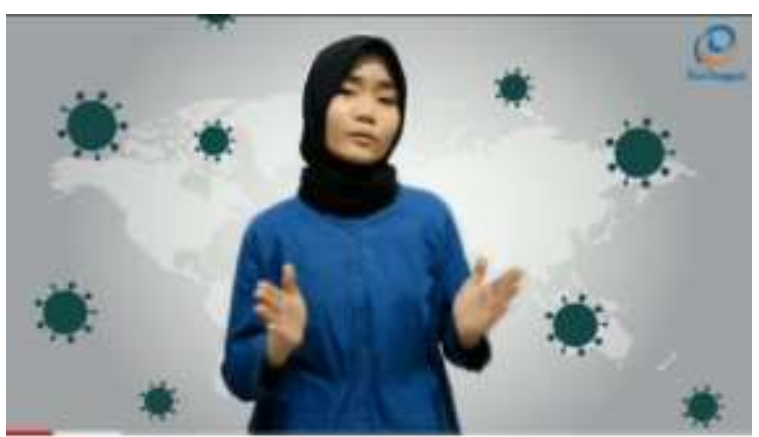

\#PHKNoWorries \#UniversitasEsaUnggul RESAH KARENA PHK? AYO BISNIS AJA!

673 x ditonton -5 bulan lalu

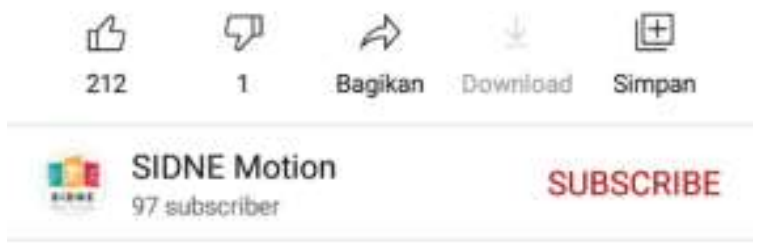

Bukan hanya membuat dan meluncurkan video kampanye, para personil yang terlibat dalam pembuatan video kampanye ini pun melakukan sosialisasi ke warga Desa Mangun Jaya, Kota Bekasi didampingi kepala desa setempat dengan tetap menerapkan protokol kesehatan seperti menggunakan masker dan tidak menciptakan kerumunan. Proses sosialisasi dilakukan dengan mengunjungi rumah beberapa warga secara bergantian untuk memaparkan materi. Terakhir, tim memberikan cinderamata kepada warga yang dikunjungi berupa stiker, pemasangan spanduk di kantor kepala desa serta memberikan plakat kepada kepala desa.

\section{Kesimpulan}

Para karyawan "korban" PHK adalah tergolong masyarakat usia produktif. Diberhentikan dari tempatnya bekerja bukanlah akhir dari produktivitas mereka. Namun demikian mereka membutuhkan banyak dukungan dari semua pihak. Pembuatan video kampanye bisa menjadi salah satu media pendukung yang menginformasikan alternatif bagi mereka untuk mulai beralih berwirausaha. Menciptakan lapangan pekerjaan sendiri dan menemukan passion mereka di bidang usaha apa pun yang halal.

\section{Daftar Pusaka}

Agesta, Budy. 2018. Pembuatan Motion Graphic Sebagai Media Promosi Untuk Proyek Purna Jual Datsun Sigap. Jurnal Ilmiah Manajemen Informatika dan Komputer. Vol. 02, No. 22, hal. $84-97$.

Astagini, Nuria. 2020. Modul Mata Kuliah Produksi Acara TV (Komersial).

Bekasi: 2020.

Dodi, 2008. Modul Software : Adobe Audition. Bandung: Elex Media Komputindo.

Kurnia, D. dkk. 2020. Manajemen Kewirausahaan. Yogayakarta: Deepublish.

Laksamana, Media. 2019. Youtube \& Google Video: Membuat, Mengedit dan Upload Video. Yogyakarta: MediaKom.

Rahmi, Kusuma. 2014. Perancangan Video Dokumenter "Autisme". Jurnal Tingkat Sarjana Senirupa dan Design. No. 1:3.

S, Curran. 2000. Motion Graphics: Graphic Design For Broadcast and Film. China: Rockpot Publisher inc.

Soeherman, Bonnie dan Cipta Halim. 2008. Membuat Sendiri Klip Animasi Multimedia. Jakarta: Elex Media Komputindo.

206 Buruh di Bekasi Terdampak Corona 1.651 diantaranya Kena PHK https://www.google.com/amp/s/megapolitan.okezon e.com/amp/2020/06/2 2/338/2234496/6-206-buruhdi-bekasi-terdampak-corona-1-651-diantaranyakena-phk

Berbisnis setelah jadi korban PHK https://www.youtube.com/watch?v=ifxaFL $\underline{\mathrm{mBpqE}}$

Data Disnaker Bekasi 601 Karyawan di PHK saat Pandemi

https://bekasi.pojoksatu.id/baca/datadisnaker-bekasi-601-karyawan-diphk-saatpandemi 
Mau Bisnis Modalnya di Bawah Rp 500 Ribu? Bisa

Banget

Lho

https://www.youtube.com/watch?v=sg4vV_ $\underline{\text { PzWVU }}$

Menaker sebut 3 Juta Pekerja Dirumahkan dan Kena PHK Imbas Corona https://www.google.com/amp/s/katadata.co.i d/amp/ameidyonasution/berita 15ee33f108fef5/menaker-sebut-3-jutapekerja-dirumahkan-dan-kena-phkimbascorona

Pekerja Dirumahkan dan Kena PHK Akibat Corona

Capai 3,05 Juta Jiwa

https://m.cnnindonesia.com/ekonomi/20200 720114203-92-

526610/pekerja-dirumahkan-dan-kena-phkakibat-corona-capai-305-juta

Permintaan Masker Tinggi, Karyawan yang Terkena PHK Ini Ketiban Rezeki https://www.youtube.com/watch?v=ifxaFL $\underline{\mathrm{mBpqE}}$ 